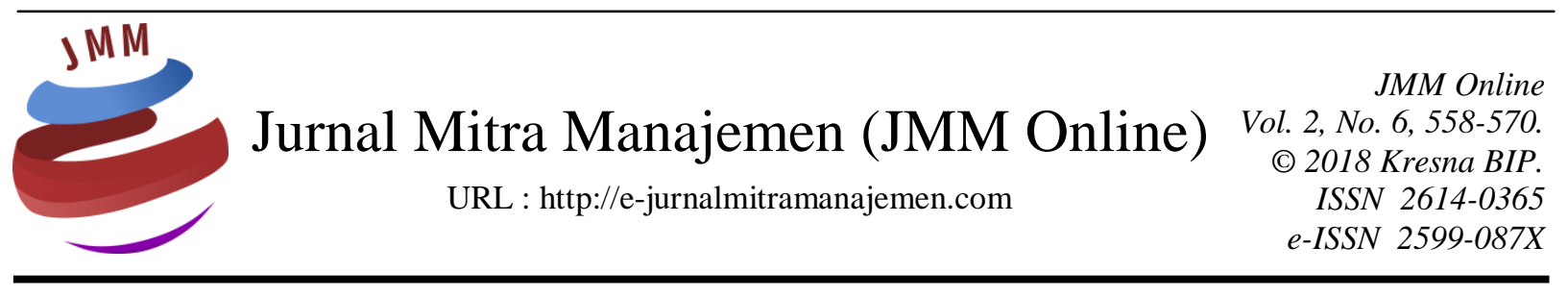

\title{
PEMBERDAYAAN KARANG TARUNA \\ (Studi Kasus Karang Taruna Sinar Muda Desa Ngabetan \\ Kecamatan Cerme Kabupaten Gresik)
}

\author{
Priyo Utomo ${ }^{1)}$, Imam Mursyid ${ }^{2)}$, Syamsul Arifin ${ }^{3)}$ \\ STIE Pemuda Surabaya
}

\section{INFORMASI ARTIKEL}

Dikirim : 31 Agustus 2018

Revisi pertama : 05 November 2018

Diterima : 09 November 2018

Tersedia online : 01 Desember 2018

Kata Kunci : Pembersayaan Karang Taruna

Email: priyoutomo.stiepemuda@gmail.com

\author{
ABSTRAK
}

Penelitian ini bertujuan untuk mengetahui sejauh mana proses pemberdayaan Karang Taruna Sinar Muda di Desa Ngabetan Kecamatan Cerme Kabupaten Gresik. Jenis penelitian yang digunakan adalah metode penelitian deskriptif kualitatif. Fokus penelitian yaitu tujuan pemberdayaan yang berdasarkan pada Permensos No 23 Tahun 2013 beberapa tahapannya yaitu persiapan pemberdayaan, pelaksanaan pemberdayaan, sampai pada pendayagunaan lanjutan.

Untuk meningkatkan sumber daya manusia Karang Taruna Sinar Muda di Desa Ngabetan dimulai dari sosialisasi program. Selanjutnya adanya pemberian motivasi kepada Anggota Karang Taruna tentang pentingnya pelatihan yang nantinya akan meningkatkan kemampuan mereka dalam berorganisasi. Selain itu dengan adanya pendayagunaan lanjutan dalam hal memberikan wewenang kepada anggota Karang Taruna Sinar Muda untuk melaksanakan kegiatan yang sudah direncanakan. Untuk meningkatkan kelembagaan Karang Taruna Sinar Muda Desa Ngabetan dimulai dengan tahapan perencanaan pemberdayaan dalam bentuk perekrutan. Selanjutnya kegiatan pemberdayaan dimulai dengan pembentukkan awal kepengurusan. Kemudian dalam tahapan pendayagunaan lanjutan, perangkat desa memberikan wewenang kepada ketua Karang Taruna Sinar Muda untuk melakukan pembentukan kepengurusan baru dengan berbagai pengembangan divisi yang ada.

Untuk mengembangkan aktivitas karang taruna memerlukan beberapa proses atau tahapan yang tidak mudah seperti halnya harus mensinergikan antara program kerja Desa dengan program kerja yang dilakukan oleh pihak Karang Taruna Sinar Muda. Peningkatkan sarana prasarana untuk kegiatan Karang Taruna Sinar Muda membutuhkan proses yang tidak mudah, mulai dari pengajuan yang nantinya akan dibawa ke Musyawarah Desa, sampai pada kesepakatan untuk menggunakan sarana prasarana yang ada untuk melakukan kegiatan yang sudah diprogramkan. Adanya upaya untuk meningkatkan jejaring antara Karang Taruna Sinar Muda dengan pihak diluar desa, akan tetapi belum maksimalnya jaringan atau mitra yang ada di desa. 


\section{PENDAHULUAN \\ Latar Belakang}

Pemuda merupakan bagian dari masyarakat yang menjadi sendi-sendi bangsa juga perlu untuk dibenahi dengan segala persoalan yang ada. Kegitan pemberdayaan merupakan implikasi dari strategi pembangunan yang berbasis pada masyarakat, termasuk pemuda. Pemberdayaan masyarakat merupakan proses meningkatkan kemampuan dan sikap kemandirian masyarakat (Totok dan Poerwoko, 2013:28). Secara sederhana, adanya kegiatan pemberdayaan adalah bagaimana membuat individu yang tidak berdaya menjadi lebih berdaya, artinya pemberdayaan memberikan suatu proses individu untuk mengembangkan kemampuannya supaya lebih berdaya atau berkemampuan. Sehingga upaya pemberdayaan sangat cocok dan potensial diberikan pada kaum muda. Dengan potensi yang dimiliki pemuda, maka pemuda perlu ikut Pemerintah dalam masyarakat berbentuk partisipan baik secara individu maupun kelompok/lembaga yang mempunyai konsentrasi kegiatan pemberdayaan pemuda dalam usaha kesejahteraan sosial di lingkungan masyarakat yang kemudian disebut sebagai pilar-pilar partisipan. Salah satu bentuk pemberdayaan yang dilakukan di desa adalah pemberdayaan Karang Taruna. Karang Taruna merupakan salah satu organisasi kemasyarakatan yang menampung aspirasi dan melibatkan generasi muda yang berkembang di desa saat ini (Risaldi, 2016). Menurut buku pedoman Karang Taruna 2010, yang dimaksud Karang Taruna adalah organisasi sosial sebagai wadah pengembangan potensi generasi muda yang tumbuh dan berkembang atas dasar kesadaran jiwa dan tanggung jawab sosial, dari, oleh dan untuk masyarakat terutama generasi muda yang berada di wilayah desa atau komunitas atau setingkat dan juga bergerak dalam bidang kesejahteraan sosial guna kemajuan bersama. Jadi pada intinya selain menampung aspirasi, karang taruna juga berperan sebagai suatu wadah untuk menanamkan rasa nasionalisme, pengembangan potensi diri dan merupakan organisasi yang bergerak di bidang sosial.

Sehubungan dengan fungsi Karang Taruna sebagai wahana pengembangan generasi muda (termasuk di dalamnya adalah pemberdayaan remaja). Maka Karang Taruna sendiri juga memiliki tugas untuk menjawab permasalahan sosial yang salah satunya adalah masalah pengangguran. Dari segi kuantitatif, jumlah organisasi Karang Taruna yang tersebar di seluruh pelosok tanah air merupakan potensi besar dan mempunyai posisi strategis bagi pemberdayaan generasi muda. Menurut catatan Direktorat Jenderal Pemberdayaan Sosial, jumlah Karang Taruna telah mencapai lebih dari 65.000 organisasi. (Riset Pusat Penelitian dan Pengembangan Usaha Kesejahteraan Sosial, akses 2012). Namun, jika ditinjau dari segi kualitas sebagian besar $(75,65 \%)$ masih memerlukan pembinaan. Pendayagunaan potensi dan posisi strategis untuk pengembangan potensi generasi muda relative belum optimal. Kondisi ini tercermin dari jumlah Karang Taruna dan percontohan baru mencapai 20,35\%, Kondisi ini juga tercermin dari hasil penelitian penjajagan tentang kondisi Karang Taruna yang dilakukan oleh Balatbangsos (2012) mengungkapkan ada beberapa permasalahan Karang Taruna yang berkaitan dengan rencana kegiatan yang belum sistematik serta dari sisi manajemen organisasi tidak berjalan dengan baik. Peneliti dalam penelitian ini mencoba merefleksikan penelitian dari Balatbangsos (2012) dengan kondisi Karang Taruna yang ada di Desa Ngabetan Kecamatan Cerme Kabupaten Gresik yaitu Karang 
Taruna Sinar Muda. Karang taruna Sinar Muda merupakan suatu bagian dari masyarakat dan program-program yang dibuat adalah realisasi nyata untuk masyarakat di sekitarnya. Karang Taruna Sinar Muda tidak hanya semata-mata sebuah organisasi, namun karang taruna ini juga sebagai wadah aspirasi masyarakat seperti kritik dan saran dalam berbagai hal, salah satunya yaitu dalam kritik perluasan lahan pabrik di sekitar desa Ngabetan. Begitu banyak hal yang dilakukan Karang Taruna untuk masyarakat sehingga partisipasinya sangat ditunggu untuk mengembangkan anggota/pemuda, masyarakat dan lingkungannya. Dengan adanya latar belakang diatas, maka peneliti tertarik untuk memperdalam kajian tentang pemberdayaan Karang Taruna melalui penelitian yang berjudul "Pemberdayaan Karang Taruna (Studi Kasus Karang Taruna Sinar Muda Desa Ngabetan Kecamatan Cerme Kabupaten Gresik)”.

\section{KAJIAN PUSTAKA}

\section{Pembangunan Berpusat Pada Masyarakat}

Pemahaman terhadap pembangunan menghasilkan ide kemajuan, berkonotasi ke depan atau ke tingkat yang lebih tinggi. Pembangunan harus dipahami sebagai suatu proses yang berdimensi jamak yang melibatkan perubahan-perubahan besar dalam struktur sosial, sikap masyarakat dan kelembagaan nasional, seperti halnya percepatan pertumbuhan ekonomi, pengurangan ketidakmerataan, dan pemberantasan kemiskinan absolut (Todaro dalam Hikayat, 2014).

Untuk mewujudkan agenda perubahan tersebut, maka pembangunan, kebijakan pembangunan, dan pembangunan kelembagaan perlu diarahkan oleh suatu paradigma baru yang berakar pada ide-ide, nilai-nilai, teknik-teknik sosial dan teknologi lokal (alternatif) (Nasdian, 2014:20). Selanjutnya Nasdian juga menambahkan bahwa logika yang dominan dan perlu dikembangkan sebagai paradigma baru tersebut adalah logika ekologi manusia yang seimbang dengan sumberdaya utama berupa sumber daya informasi dan prakarsa kreatif dengan memberi peran kepada masyarakat bukan sebagai objek, tetapi lebih dari itu sebagai subyek yang menetapkan tujuan, mengendalikan sumber daya, dan mengarahkan proses yang mempengaruhi kehidupannya. Paradigma ini dikenal sebagai people centred development atau pembangunan yang berpusat pada masyarakat. Salah satu tantangan yang penting bagi pembangunan yang berpusat pada masyarakat adalah mengubah orientasi birokrasi pembangunan ekonomi pemerintah agar menjadi agensi-agensi yang mampu meningkatkan kapasitas kelembagaan dan pemberdayaan organisasi-organisasi sosial di tingkat lokal dan komunitas. Hal ini sangat relevan dengan implementasi prinsipprinsip desentralisasi dan kesetaraan dalam pengembangan kelembagaan pembangunan. Model pendekatan pembangunan yang berpusat pada masyarakat lebih menekankan kepada pemberdayaan, yaitu menekankan kenyataan pengalaman masyarakat dalam sejarah penjajahan dan posisinya dalam tata ekonomi internasional

\section{Pemberdayaan Masyarakat}

Nasdian (2014:89-90) menjelaskan bahwa pemberdayaan secara konseptual pada intinya membahas bagaimana individu, kelompok atau komunitas berusaha mengkontrol kehidupan mereka sendiri dan mengusahakan untuk membentuk masa depan sesuai dengan keinginan mereka. Suharto (2006:22) juga menjelaskan bahwa 
pemberdayaan merupakan penguat kapasitas para penerima pelayanan sosial sehingga memiliki kemampuan dan kepercayaan diri dalam memenuhi kebutuhan dasarnya. Permendagri RI No 7 Tahun 2007 tentang Kader Pemberdayaan Masyarakat, dinyatakan bahwa pemberdayaan masyarakat adalah suatu strategi yang digunakan dalam pebangunan masyarakat sebagai upaya untuk menunjukkan kemampuan dan kemandirian dalam kehidupan bermasyarakat, berbangsa, dan bernegara. Dalam hal ini, pemberdayaan masyarakat memerlukan keterlibatan dari perangkat pemerintah daerah serta berbagai pihak untuk memberikan kesempatan dan menjamin keberlanjutan berbagai hasil yang dicapai. Tujuan yang ingin dicapai dari pemberdayaan adalah untuk membentuk individu dan masyarakat menjadi mandiri. Kemandirian tersebut meliputi kemandirian berpikir, bertindak dan mengendalikan apa yang mereka lakukan tersebut.

\section{Pemberdayaan Karang Taruna}

Pada pasal 3 Permensos No 23 Tahun 2013 juga menyebutkan bahwa pemberdayaan karang taruna bertujuan untuk:

1. Meningkatkan kapasitas sumber daya manusia Karang Taruna

2. Meningkatkan kelembagaan Karang Taruna

3. Mengembangkan aktivitas Karang Taruna

4. Meningkatkan sarana prasarana kegiatan Karang Taruna

5. Mengembangkan Jejaring Kerja Karang Taruna

Pada pasal 22 Permensos No 23 Tahun 2013 juga dijelaskan ada beberapa tahapan dalam pemberdayaan Karang Taruna, diantaranya:

1. Persiapan Pemberdayaan

2. Pelaksanaan Pemberdayaan

3. Pendayagunaan Lanjutan

Berdasarkan pada kajian atau telaah pustaka di atas, maka untuk memudahkan peneliti dalam menggali informasi tentang penelitian pemberdayaan Karang Taruna Sinar Muda di Desa Ngabetan Kecamatan Cerme Kabupaten Gresik, maka peneliti menggambarkannya dalam kerangka konseptual dibawah ini:

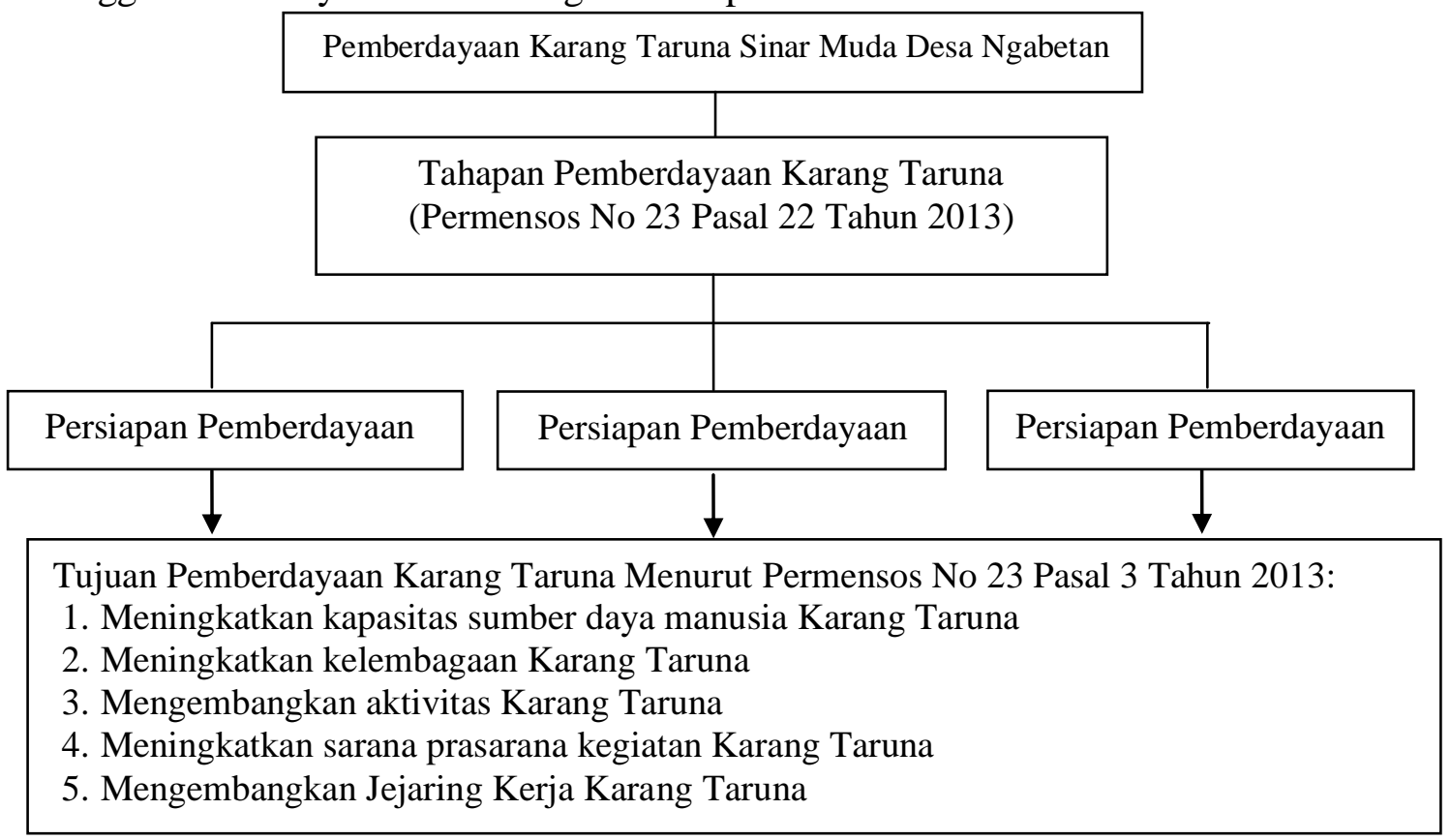


Dalam kerangka konseptual diatas dapat dijelaskan tahapan pemberdayaan Karang Taruna sesuai dengan Permensos No 23 Tahun 2013 tentang Pemberdayaan Karang Taruna dimulai dengan persiapan pemberdayaan karang taruna. Kemudian dilanjutkan dengan pelaksanaan pemberdayaan karang taruna setelah itu diadakannya pendayagunaan lanjutan. Dengan adanya 3 (tiga) tahapan yang dilalui diharapkan tujuan pemberdayaan karang taruna tercapai sesuai dengan Permensos No 23 Tahun 2013 tentang Pemberdayaan Karang Taruna

\section{METODE PENELITIAN Informan Penelitian}

Ketentuan informannya adalah sebagai berikut:

1. Mengetahui serta bertanggungjawab langsung dalam proses pemberdayaan Karang Taruna

2. Terlibat dalam tahapan pemberdayaan Karang Taruna

3. Mengetahui kegiatan Karang Taruna

Dari beberapa parameter atau ketentuan informan diatas, maka peneliti menentukan beberapa informan dibawah ini untuk mendapatkan data yang sesuai dengan tujuan penelitian. Berikut ini tabel tentang informan penelitian:

Tabel 1. Data Informan

\begin{tabular}{|l|l|l|}
\hline No & Informan & Jumlah Informan \\
\hline 1 & Kepala Desa Ngabetan & 1 Orang \\
\hline 2 & Sekretaris Desa Ngabetan & 1 Orang \\
\hline 3 & Kaur Pemerintahan & 1 Orang \\
\hline 4 & Kepala Dusun Kejambon, Ngabetan, Sukorejo/Bendung & 3 Orang \\
\hline 5 & Ketua Karang Taruna Sinar Muda & 1 Orang \\
\hline 6 & Pengurus Karang Taruna Sinar Muda & 2 Orang \\
\hline 7 & Perwakilan tokoh masyarakat Desan Ngabetan & 2 Orang \\
\hline \multicolumn{2}{|l|}{ Total Informan } & 11 Orang \\
\hline
\end{tabular}

\section{Teknik Pengumpulan Data}

Pengumpulan data dilakukan untuk memperoleh informasi yang dibutuhkan dalam rangka mencapai tujuan penelitian (Gulo, 2010:110). Adapun beberapa teknik pengumpulan data yang dilakukan oleh peneliti menggunakan beberapa teknik, yaitu wawancara dan dokumentasi.

\section{Teknik Analisis Data}

Teknik analisa data yang digunakan dalam penelitian ini menggunakan empat komponen analisis, yaitu sebagai berikut :

1. Pengumpulan Data (Data Collection)

2. Reduksi Data

3. Display Data

4. Verifikasi dan Penegasan Kesimpulan (Conclusion Drawing and Verification) 
Proses analisis data secara interaktif dapat disajikan dalam bentuk skema sebagia berikut :

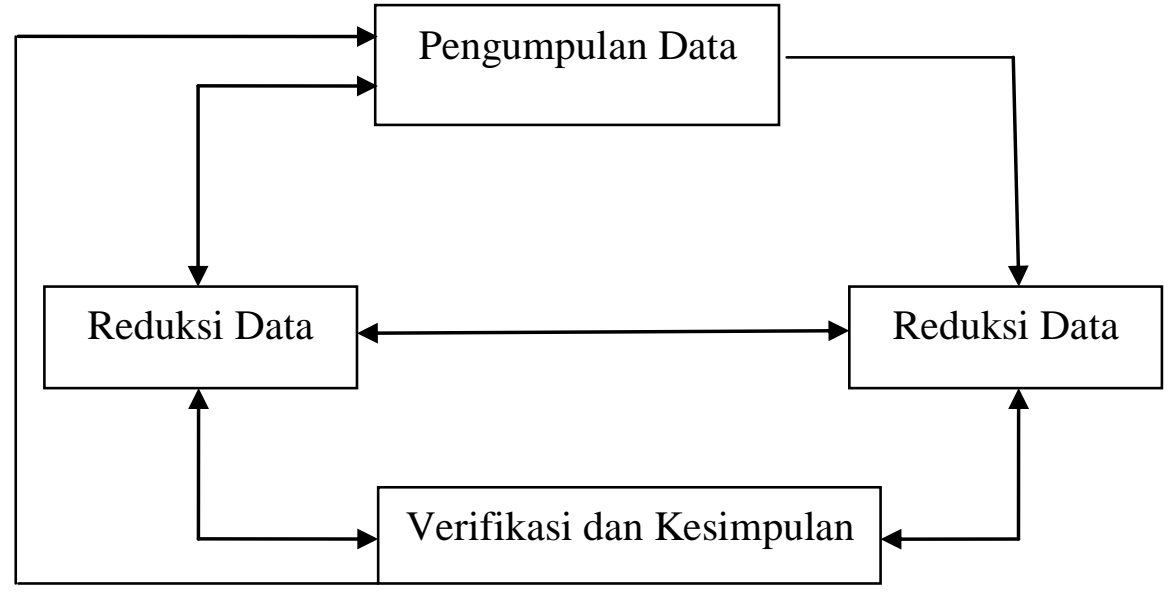

\section{Temuan Penelitian}

Dalam upaya pencapaian tujuan memberdayakan Karang Taruna Sinar Muda yang didasarkan pada Permensos No 23 Tahun 2013 tentang Pemberdayaan Karang Taruna yang dijadikan fokus penelitian adalah tahapan dalam pemberdayaan Karang Taruna dalam pencapaian tujuan Pemberdayaan Karang Taruna sebagai berikut:

1. Meningkatkan Kapasitas Sumber Daya Manusia Karang Taruna

Tujuan pemberdayaan ini mengacu pada pertumbuhan dan perkembangan setiap anggota karang taruna yang memiliki kualitas, terampil, cerdas, inovatif, serta memiliki kesadaran dan tanggungjawab sosial dalam mengembangkan generasi muda yang ada di wilayah desa. Dalam uaya pencapaian tujuan ini dilakukan dengan berbagai tahapan seperti (1) Persiapan pemberdayaan dalam rangka pencapaian tujuan meningkatkan kapasitas sumber daya manusia dimulai dengan adanya sosialisai program sampai pada membangkitkan kesadaran dari keanggotaan karang taruna tentang pentingnya proses pelatihan yang nantinya akan meningkatkan kemampuan mereka dalam keorganisaian. (2) Pelaksanaan pemberdayaan dalam pencapaian tujuan peningkatan kapasitas sumber daya manusia dilakukan dengan mengadakan pelatihan-pelatihan terhadap anggota dan pengurus Karang Taruna Sinar Muda Desa Ngabetan. Akan tetapi masih belum berjalan optimal ketika pengurus Karang Taruna Sinar Muda tidak hadir secara menyeluruh di kegiatan pelatihan tersebut. (3) Pendayagunaan lanjutan dalam hal memberikan wewenang kepada anggota Karang Taruna Sinar Muda untuk melaksanakan kegiatan yang sudah direncanakan secara mandiri tetapi juga melalui pengawasan dari perangkat Desa Ngabetan. Sehingga dengan adanya tahapan ini, dapat menguji kemampuan sumber daya manusia Karang Taruna Sinar Muda dalam berorganisasi.

2. Meningkatkan Kelembagaan Karang Taruna

Tujuan peningkatan Kelembagaan Karang Taruna Sinar Muda Desa Ngabetan tertuju pada tersusunnya kelembagaan atau kepengurusan karang taruna itu sendiri. Dalam pelaksanaan untuk mencapai tujuan pemberdayaan ini ada beberapa tahapan yang harus dilalui, diantaranya (1) Kegiatan persiapan 
pemberdayaan dalam rangka peningkatan kelembagaan Karang Taruna Sinar ialah munculya ide untuk mengumpulkan pemuda pemudi yang berpotensi di Desa Ngabetan, akan tetapi kendalanya adalah menguugah kesadaran para pemuda pemudi tersebut. Kemudian ada salah satu pemuda yang memiliki inisiatif untuk membentuk kepengurusan kecil dalam keorganisasian Karang Taruna, (2) Pelaksanaan kegiatan pemberdayaan, pelaksanaan pemberdayaan dimulai dengan realisasi ide untuk mengumpulkan pemuda pemudi Desa Ngabetan untuk membentuk kelembagaan Karang Taruna, (3) Pendayagunaan lanjutan, perangkat desa memberikan wewenang kepada ketua Karang Taruna Sinar Muda untuk melakukan pembentukan kepengurusan baru dengan berbagai pengembangan divisi yang ada. Sehingga yang awalnya hanya kurang lebih 15 orang, sekarang berkembang menjadi kurang lebih 50 orang yang tersebar ke berbagai divisi.

\section{Mengembangkan Aktivitas Karang Taruna}

Kegiatan pemberdayaan berikutnya betujuan untuk mengembangkan aktivitas Karang Taruna Sinar Muda di Desa Ngabetan. Ada beberapa tahapan pemberdayaan menuju tercapainya tujuan pemberdayaan tersebut, diantaranya: (1) Persiapan Pemberdayaan, pada tahapan ini dimulai dengan adanya sosialisasi program maka program yang dilaksanakan oleh Karang Taruna Sinar nantinya, sehingga dapat mendukung program yang ada di Desa Ngabetan. Peneliti juga mendapatkan salah satu program desa adalah menanggulangi kemiskinan yaitu dengan menambahkan subsidi beras raskin di tiap dusun (RPJMDes 2016), kemudian program kerja dari pihak Karang taruna Sinar Muda dalam mendukung kegiaytan di atas ada pengembangan aktivitas yaitu dalam bentuk BakSos (Bakti Sosial) setiap 3 bulan sekali, (2) Pelaksanaan pemberdayaan, untuk mencapai tujuan kegiatan pengembangan aktivitas karang Taruna dilakukan dengan memberikan kebebasan kepada Karang Taruna Sinar Muda untuk melakukan pengembangan aktivitas dalam program kerjanya. Peneliti juga mendapatkan tentang pelaksanaan pelatihan komputer oleh Karang Taruna Sinar Muda kepada murid dari Madrasah Ibtida'yah Maba'ul Ma'arif, (3) Pendayagunaan Lanjutan, Pengembangkan aktivitas karang taruna memerlukan beberapa proses atau tahapan yang tidak mudah seperti halnya harus mensinergikan antara program kerja Desa dengan program kerja yang dilakukan oleh pihak Karang Taruna Sinar Muda. Dalam hal pengembangan aktivitas, para anggota pengurus Karang Taruna Sinar Muda diberi keleluasaan untuk menentukan program kerja, selama program kerja tersebut dapat membawa manfaat yang baik bagi masyarakat Desa Ngabetan.

\section{Meningkatkan Sarana Prasarana Kegiatan Karang Taruna}

Tujuan pemberdayaan karang taruna berikutnya adalah meningkatkan sarana prasarana kegiatan Karang taruna Sinar Muda di Desa Ngabetan yang akan dicapai melalui tahapan-tahapan pemberdayaan sebagai berikut: (1) Persiapan Pemberdayaan. Dalam tahapan ini kegiatan pertama yang dilakukan adalah mengidentifikasi terlebih dahulu sarana prasarana yang dibutuhkan oleh Karang Taruna Sinar Muda dalam pelaksanaan kegiatannya. (2) Pelakasanaan pemberdayaan dalam rangka peningkatan sarana prasarana Karang Taruna 
dilakukan dengan pengajuan proposal tentang sarana prasarana yang dibutuhkan oleh pengurus Karang Taruna Sinar Muda dalam melakukan kegiatan yang sudah diprogramkan, akan tetapi waktu yang dibutuhkan untuk pencairan dana tersebut juga tidak bisa berjalan cepat, harus melalui proses terlebuh dahulu. Mulai dari pengajuan proposal, sampai pada proposal tersebut dibawa ke musyawarah desa. (3) Pemberdayaan lanjutan, pihak perangkat desa memberikan wewenang tersendiri untuk para pengurus Karang Taruna Sinar Muda dalam mengajukan penambahan atau peningkatan sarana prasarana yang ada, tetapi dalam batas yang wajar. Seperti yang diungkapkan oleh Desa Ngabetan Bapak Drs. Sanadi, S.Pd sebagai berikut:

\section{Mengembangkan Jejaring Kerja Karang Taruna}

Untuk mencapai tujuan pengembangan jejaring kerja Karang Taruna Sinar Muda ada beberapa tahapan yang harus dilalui diantaranya: (1) Persiapan pemberdayaan dalam rangka pencapaian tujuan pemberdayaan yaitu mengembangkan jejaring kerja Karang Taruna Sinar Muda dilakukan dengan memberikan daftar kepada pengurus Karang Taruna tentang perusahaan maupun UMKM di sekitar wilayah Desa Ngabetan. (2) Pelaksanaan Pemberdayaan. Dalam pelaksanaannya, untuk menjalin mitra dengan perusahaan sekitar, para pengurus Karang Taruna sinar Muda mengalami beberapa kesulitan. Ketika pengurus Karang Taruna kesulitan menjalin jejaring kerja dengan UMKM maupun perusahaanperusahaan di daerah Desa Ngabetan, maka mereka akan mencari mitra di luar daerah desa serta menjalin kerjasama dengan masyarakat setempat supaya dapat berpartisipasi dalam kegiatan yang diadakan oleh Karang Taruna Sinar Muda Desa Ngabetan. (3) Pendayagunaan lanjutan dalam rangka menuju peningkatan jejaring Karang taruna adalah dengan adanya kebebasan dari pengurus karang taruna untuk mencari sponsor kegiatan jika dana yang disediakan desa dirasa kurang menutupi kekurangan dana kegiatan. Sehingga untuk mengembangkan jejaring untuk pencarian dana utamanya dilakukan secara mandiri oleh pengurus Karang Taruna Sinar Muda. Sehingga dengan adanya upaya tersebut, maka kegiatan yang telah diprogramkan dapat berjalan dengan lancar

\section{PEMBAHASAN}

1. Meningkatkan Kapasitas Sumber Daya Manusia Karang Taruna

Perencanaan pemberdayaan ada beberapa kegiatan yang dilakukan diantaranya adalah sosialisasi program, Sosialisasi program dalam penelitian ini merupakan kegiatan dalam membuka wawasan dan kesadaran pengurus Karang Taruna dalam pentingnya pemberdayaan. Desa Ngabetan memiliki beberapa program untuk itu, seperti adannya pelatihan keorganisasian, pelatihan kerajinan, dan lain sebagainya. Sehingga dengan adanya pelatihan-pelatihan yang akan meningkatkan sumber daya manusia tersebut maka para pengurus Karang Taruna Sinar Muda memiliki kemampuan dan kepercayaan diri dalam memenuhi tuntutannya sebagai sumber daya manusia yang nantinya akan mengembangkan organisasi. Hal ini sejalan dengan teori yang diungkapkan oleh Suharto (2006:22) yang menjelaskan bahwa pemberdayaan merupakan penguat kapasitas para penerima pelayanan sosial sehingga memiliki kemampuan dan kepercayaan diri 
dalam memenuhi kebutuhan dasarnya. Kegiatan selanjutnya adalah pelaksanaan kegiatan pemberdayaan, ada beberapa kendala yang dihadapi, seperti kurang aktifnya anggota atau pengurus karang tarunan yang mengikuti kegiatan peningkatan sumber daya manusia tersebut. Kepala Desa juga sudah menyinggung bahwa kegiatan ini juga demi kepentingan pengurus karang taruna itu sendiri. Lebih lanjut Anwar (2007: 35-36) model pembelajaran pemberdayaan meliputi komponenkomponen sebagai berikut: 1) Model pembelajaran makro, komponennya terdiri atas a) penyadaran, b) perencanaan, c) pengorganisasian, d) penggerakan, e) penilaian, dan f) pengembangan. Dengan adanya pemberdayaan lanjutan, perangkat desa mengetahui sejauh mana kemampuan para pengurus dalam melakukan pengambilan keputusan. Hal serupa juga diungkapkan Kesi (2013: 6) keberdayaan masyarakat dapat diukur melalui tiga aspek 1) kemampuan dalam mengambil keputusan, 2) kemandirian dan 3) kemampuan memanfaatkan usaha untuk masa depan.

\section{Meningkatkan Kelembagaan Karang Taruna}

Tahapan perencanaan pemberdayaan perangkat desa mulai mempersiapkan beberapa kader pemuda yang ada di setiap dusun yang ada di lingkungan Desa Ngabetan untuk pembentukan karang Taruna Sinar Muda. Dengan mensosialisasikan pentingnya pembentukan Karang Taruna sebagai organisasi pemuda desa yang nantinya akan mengembangkan desa sampai pada memberikan motivasi untuk melakukan pembentukan. Hal ini sesuai dengan penekanan pada Pasal 1 ayat 1 Permensos No 23 Tahun 2013 tentang Pemberdayaan Karang Taruna menyebutkan bahwa Karang Taruna adalah organisasi sosial kemasyarakatan sebagai wadah dan sarana pengembangan setiap anggota masyarakat yang tumbuh dan berkembang atas dasar kesadaran dan tanggung jawab sosial dari, oleh, dan untuk masyarakat terutama generasi muda di wilayah desa atau kelurahan atau nama lain yang sejenis terutama bergerak di bidang penyelenggaraan kesejahteraan sosial.

Pelaksanaan pemberdayaan untuk menguatkan kelembagaan Karang taruna juga mengalami beberapa hambatan seperti kurangnya kesadaran dari pemuda pemudi desa untuk melakukan pengembangan potensi diri, sehingga ketika diajak untuk mengikuti organisasi pemuda seperti Karang Taruna malah mereka lebih memilih mengundurkan diri atau tidak mengikutinya. Tetapi dengan kemauan yang keras serta motivasi dari perangkat Desa Ngabetan akhirnya Karang Taruna Sinar Muda dapat terbentuk. Seperti yang diungkapkan oleh Soeharto (dalam Hairi (2012:174) bahwa ada empat pilar dalam indikator keberdayaan yaitu a) tingkat kesadaran dan keinginan berubah (power to); b) tingat kemampuan meningkatkan kapasitas untuk memperoleh akses (power within); c) tingkat kemampuan menghadapi hambatan (power over); d) tingkat kemampuan kerjasama dan solidaritas (power with). Derajat keberdayaan suatu kelompok atau individu dimulai dan paling tinggi tingkatannya, dengan adanya kesadaran dan kemauan untuk (power to) berubah dan atau mengubah sesuatu menjadi lebih baik. Pendayagunaan lanjutan yang dilakukan untuk meningkatkan kelembagaan Karang Taruna Sinar Muda desa Ngabetan dimulai dengan memberikan kewenangan kepada ketua terpilih untuk menyusun struktur kepengurusan secara mandiri. Selanjutnya kegiatan pemberdayaan dimulai dengan pembentukkan awal kepengurusan yang menghadapi 
kesulitan dalam pembentukannya, akan tetapi dengan usaha keras dari setiap anggota yang awal mula terbentuk maka berkembang pesat menjadi banyak.

\section{Mengembangkan Aktivitas Karang Taruna}

Tahapan perencanaan pemberdayaan ini kegiatan pertama yang dilakukan adalah sosialisasi program dari Desa Ngabetan. Dengan adanya sosialisasi program maka program yang dilaksanakan oleh Karang Taruna Sinar Nantinya dapat mendukung program yang ada di Desa Ngabetan. Peneliti juga mendapatkan salah satu program desa adalah menanggulangi kemiskinan yaitu dengan menambahkan subsidi beras raskin di tiap dusun (RPJMDes 2016), kemudian program kerja dari pihak Karang taruna Sinar Muda dalam mendukung kegiatan di atas ada pengembangan aktivitas yaitu dalam bentuk BakSos (Bakti Sosial) setiap 3 bulan sekali. Dengan adanya sinergi antara program desa dengan program Karang Taruna Sinar Muda dalam bidang pengabdian masyarakatdiharapkan tingkat penduduk miskin daerah Desa Ngabetan dapat berkurang. Kegiatan selanjutnya adalah pelaksanaan kegiatan pemberdayaan, dalam pelaksanaannya kegiatan pengembangan aktivitas karang Taruna. Dalam hal pencapaian tujuan pengembangan aktivitas Karang Taruna Sinar yang ada di Desa Ngabetan Kecamatan Cerme, perangkat desa melakukan pendayagunaan lanjutan dengan memberikan kebebasan dalam mengembangkan program berikutnya setelah diadakan evaluasi.

Dengan adanya beberapa sumber di atas, maka peneliti menyimpulkan bahwa untuk mengembangkan aktivitas karang taruna memerlukan beberapa proses atau tahapan yang tidak mudah seperti halnya harus mensinergikan antara program kerja Desa dengan program kerja yang dilakukan oleh pihak Karang Taruna Sinar Muda. Dalam hal pengembangan aktivitas, para anggota pengurus Karang Taruna Sinar Muda diberi keleluasaan untuk menentukan program kerja, selama program kerja tersebut dapat membawa manfaat yang baik bagi masyarakat Desa Ngabetan. Sesuai dengan pendapat Ambar Teguh (2004: 80-81) bahwa sesuatu yang diharapkan dari pemberdayaan yang merupakan visualisasi dari pembangunan sosial ini diharapkan dapat mewujudkan komunitas yang baik dan masyarakat yang ideal.

\section{Meningkatkan Sarana Prasarana Kegiatan Karang Taruna}

Tujuan pemberdayaan karang taruna berikutnya adalah meningkatkan sarana prasarana kegiatan Karang taruna Sinar Muda di Desa Ngabetan yang akan dicapai melalui tahapan-tahapan pemberdayaan sebagai berikut persiapan pemberdayaan, pelaksanaan pemberdayaan dampai pada pendayagunaan lanjutan. Dalam tahapan persiapan pemberdayaan ini kegiatan pertama yang dilakukan adalah mengidentifikasi terlebih dahulu sarana prasarana yang dibutuhkan oleh Karang Taruna Sinar Muda dalam pelaksanaan kegiatannya. Peneliti juga mendapatkan salah satu program Memberikan pendidikan bagi warga belajar yang putus sekolah / belum melaksanakan wajib belajar 9 tahun sesuai Permendiknas melalui kegiatan KF (Keaksaraan Fungsional). (Program Kerja Kartar Sinar Muda 2016). Dengan adanya salah satu program keilmuan ini maka tidak sedikit sarana yang harus 
dipersiapkan, mulai dari area belajarnya, peralatan gratis dalam proses belajar mengajarnya dan lain sebagainya.

Kegiatan berikutnya ialah pelaksanaan pemberdayaan untuk meningkatkan sarana prasarana dengan memberikan motivasi kepada Karang Taruna dalam menjalankan program mereka dengan sarana prasarana yang seadanya terlebih dahulu sembari menunggu dana untuk penambahan sarana prasarana. Dalam hal kegiatan pemberdayaan lanjutan, pihak perangkat desa memberikan wewenang tersendiri untuk para pengurus Karang Taruna Sinar Muda dalam mengajukan penambahan atau peningkatan sarana prasarana yang ada, tetapi dalam batas yang wajar. Peningkatkan sarana prasarana dari Karang Taruna Sinar Muda membutuhkan proses yang tidak mudah, mulai dari pengajuan yang nantinya akan dibawa ke Musyawarah Desa, sampai pada kesepakatan untuk menggunakan sarana prasarana yang ada untuk melakukan kegiatan yang sudah diprogramkan.

5. Mengembangkan Jejaring Kerja Karang Taruna

Dalam tahapan ini kegiatan pertama yang dilakukan adalah mensosialisasikan kepada para pengurus Karang Taruna Sinar Muda tentang potensi desa dalam bidang perekonomian. untuk membangun jejaring kerja di kalangan pengurus Karang Taruna Sinar Muda dibutuhkan pemahaman yang mendalam tentang potensi yang ada di desa ngabetan itu sendiri mas. Kemudian hal tersebut berkaitan juga dengan peningkatkan hubungan kemitraan antara Karang Taruna Sinar Muda dengan pihak luar seperti kelompok usaha, UMKM, maupun perusahaan yang menjadi mitra kerja Desa Ngabetan. Dalam pelaksanaannya, untuk menjalin mitra dengan perusahaan sekitar, para pengurus Karang Taruna sinar Muda mengalami beberapa kesulitan minimnya hubungan kemitraan antara perusahaan di wilayah Ngabetan dengan perangkat desa sendiri. Sehingga untuk memenuhi kebutuhan pendanaan, akhirnya pihak karang taruna sinar menjalin hubungan dengan masyarakat sekitar. Seperti pendapat yang diungkapkan oleh Mustofa kamil (2011:56-57) bahwa pengorganisasian masyarakat merupakan karakteristik pemberdayaan yang mengarah pada tujuan untuk mengaktifkan masyarakat serta adanya pendekatan partisipatif yang menekankan terciptanya situasi yang memungkinkan setiap anggota masyarakat terlibat dalam proses pemberdayaan.

Pendayagunaan lanjutan dalam rangka menuju peningkatan jejaring Karang taruna adalah dengan adanya kebebasan dari pengurus karang taruna untuk mencari sponsor kegiatan jika dana yang disediakan desa dirasa kurang menutupi kekurangan dana kegiatan. Adanya upaya untuk meningkatkan jejaring antara Karang Taruna Sinar Muda dengan pihak diluar desa, akan tetapi belum maksimalnya jaringan atau mitra yang ada di desa. Sehingga untuk mengembangkan jejaring untuk pencarian dana utamanya dilakukan secara mandiri oleh pengurus Karang Taruna Sinar Muda. Sehingga dengan adanya upaya tersebut, maka kegiatan yang telah diprogramkan dapat berjalan dengan lancar. 


\section{KESIMPULAN DAN SARAN}

Penelitian ini didasarkan pada belum optimalnya pelaksanaan pencapaian tujuan memberdayakan Karang Taruna Sinar Muda yang didasarkan pada Permensos No 23 Tahun 2013 tentang Pemberdayaan Karang Taruna. Sehingga dalam penelitian ini yang dijadikan fokus penelitian adalah tahapan dalam pemberdayaan Karang Taruna dalam pencapaian tujuan Pemberdayaan Karang Taruna. Damal penelitian ini, peneliti menyimpulkan bahwa untuk meningkatkan sumber daya manusia Karang Taruna Sinar Muda di Desa Ngabetan dimulai dari sosialisasi program. Selanjutnya adanya pemberian motivasi kepada Anggota Karang Taruna tentang pentingnya pelatihan yang nantinya akan meningkatkan kemampuan mereka dalam berorganisasi. Selain itu dengan adanya pendayagunaan lanjutan dalam hal memberikan wewenang kepada anggota Karang Taruna Sinar Muda untuk melaksanakan kegiatan yang sudah direncanakan. Untuk meningkatkan kelembagaan Karang Taruna Sinar Muda Desa Ngabetan dimulai dengan tahapan perencanaan pemberdayaan dalam bentuk perekrutan. Selanjutnya kegiatan pemberdayaan dimulai dengan pembentukkan awal kepengurusan. Kemudian dalam tahapan pendayagunaan lanjutan, perangkat desa memberikan wewenang kepada ketua Karang Taruna Sinar Muda untuk melakukan pembentukan kepengurusan baru dengan berbagai pengembangan divisi yang ada.

Untuk mengembangkan aktivitas karang taruna memerlukan beberapa proses atau tahapan yang tidak mudah seperti halnya harus mensinergikan antara program kerja Desa dengan program kerja yang dilakukan oleh pihak Karang Taruna Sinar Muda. Peningkatkan sarana prasarana untuk kegiatan Karang Taruna Sinar Muda membutuhkan proses yang tidak mudah, mulai dari pengajuan yang nantinya akan dibawa ke Musyawarah Desa, sampai pada kesepakatan untuk menggunakan sarana prasarana yang ada untuk melakukan kegiatan yang sudah diprogramkan. Adanya upaya untuk meningkatkan jejaring antara Karang Taruna Sinar Muda dengan pihak diluar desa, akan tetapi belum maksimalnya jaringan atau mitra yang ada di desa.

\section{DAFTAR PUSTAKA}

Ambar Teguh. 2004. Kemitraan dan Model- model Pemberdayaan. Yogyakarta: Gava Media

Anwar. 2007. Manajemen Pemberdayaan Perempuan (Perubahan Sosial Melalui Pembelajaran Vocational Skills pada Keluarga Nelayan). Bandung: Alfabeta.

Gulo, W. 2010. Metodologi Penelitian. Jakarta: Grasindo.

Haihari, Firmansyah. 2012. Ketercapaian Indikator Keberdayaan Masyarakat dalam Program Pemberdayaan Fakir Miskin (P2FM) di Kota Banjarmasin. Jurnal Agribisnis Volume 02, Nomor 02, Tahun 2012 Halaman 172-180.

Hikmat, Harry. 2014. Analisis Dampak Lingkungan Sosial: Strategi Menuju Pembangunan Berpusat Pada Rakyat (People Centred Development). Jakarta: Universitas Indonesia.

Mustofa Kamil. 2013. Pendidikan Non Formal Pengembangan Melalui Pusat Kegiatan Belajar Mengajar (PKBM) di Indonesia (Sebuah Pembelajaran dari Komikan di Jepang). Bandung: Alfabeta.

Nasdian, Fredian Tonny. 2014. Pengembangan Masyarakat Edisi 1. Jakarta: Yayasan Pustaka Obor Indonesia. 
Permendagri RI No 7 Tahun 2007 Tentang Kader Pemberdayaan Masyarakat Permensos No 23 Tahun 2013 Tentang Pemberdayaan Karang Taruna

Risaldi, Heldi. 2016. Pembinaan Kepala Desa dalam Kegiatan Pemuda di Kota Bangun Seberang Kecamatan Kota Bangun Kabupaten Kutai Kertanegara. EJournal Ilmu Pemerintahan, Volume 4, No 1, 2016:515-526.

Riset Pusat Penelitian dan Pengembangan Usaha Kesejahteraan Sosial, akses 2012.

Suharto, Edi. 2006. Membangun Masyarakat, Memberdayakan Rakyat: Kajian Strategis Pembangunan Kesejahteraan Sosial dan Pekerjaan Sosial (Edisi Ke2). Bandung: Refika Aditama.

Totok dan Poerwoko Soebiato. 2013. Pemberdayaan Masyarakat. Dalam Perspektif Kebijakan Publik. Bandung : Alfabeta 